\title{
1960-1963 Dönemi İşçi Eylemlerine Aşağıdan Bakmak
}

\author{
FEYZA TURGAY* \\ feyzaturgay@gmail.com \\ ORCID ID: 0000-0001-7327-1854
}

\begin{abstract}
Öz: 1960 sonrası yasalaşan sendikal hakların işçi hareketinin ve sendikaların bir katkısı olmadan, asker-bürokrat-aydın elitlerin çabalarıyla sağlandiğg değerlendirmesi çalışma ilişkileri ve emek tarihi yazınında geniş bir yer tutmaktadır. Bu konudaki genel eğilim hakların oluşum sürecinde iş̧̧i hareketinin rolünü yok saymak biçiminde şekillenmiş olsa da kanımızca böyle bir değerlendirme eksik kalacaktır. Konu diğer boyutlarıyla birlikte incelemeye değerdir. Türkiye'de yaygın olarak tercih edilen, iş̧̧i sınıfı mücadelesini veya birikimini 1960'lardan başlatma eğilimi, o tarihte yükselen mücadelenin yalnızca Anayasa ve yasalarla bağlantılı olduğunu düşünmek anlamına gelir. Böyle bir düşünce 1960 öncesi birikimi yok saymaya, dahası toplumsal yaşamın çok faktörlü, çok yönlü ve çok düzeyli gelişim sürecini ihmal etmeye yol açacaktır. Bu çalışmada Türkiye'de 1961 Anayasası ile anayasal güvenceye kavuşturulan grevli toplu sözleşmeli sendikal hakların yasalaşma aşamasında (1960-1963) gerçekleşen belli başlı işçi eylemleri incelenerek, işçi sınıfının eylemlilik birikimi ve sürece olan katkıları ortaya konmaya çalışılacaktır.
\end{abstract}

Anahtar kelimeler: Grev hakkı, Sendikal haklar, 1961 Anayasası, İş̧i eylemleri.

\section{Giriş}

Türkiye'de sosyal hakların özel olarak da sendikal hakların yasalaşma sürecine baktığımızda mevzuatın Batılı sanayileşmiş ülkelere göre kronolojik olarak oldukça geç oluştuğunu söylemek mümkündür. Bunun pek çok sebebi olmakla birlikte, şüphesiz en belirleyici olanı Türkiye'de sanayileşmenin gecikmesine bağlı olarak işçi sınıfı oluşumunun da gecikmiş olmasıdır. Osmanlı'da çalışma yaşamına ilişkin ilk düzenlemelerin 1850'li yıllara uzandığı ileri sürülse de doğrudan toplu iş ilişkilerine yönelik ilk yasa 1909 tarihli Tatil-i Eşgal Kanunu, çalışma ilişkilerini bütünsel bir biçimde düzenleyen ve grev hakkına ilişkin katı yasakların yer aldığı ilk iş yasası ise 1936 tarihlidir. 1936 tarihli ve 3008 sayılı İş Kanunu'nda yer alan cezai yaptırımlı grev yasağına rağmen sendikal örgütlenmeye ilişkin hukuki bir yasak yoktu. Ancak 1938 tarihli ve 3512 sayılı Cemiyetler Kanunu ile "sınıf esasına veya adına dayanan" cemiyetlerin kurulması yasaklandı. Bu düzenleme ile sınıf esasına dayalı cemiyetler olan sendikaların kurulması, fiili engeller yanı sıra hukuken de yasaklanmış oluyor, böylece yasa,

\footnotetext{
* Arş. Gör., Kocaeli Üniversitesi, İ̇BF, Çalışma Ekonomisi ve Endüstri İlişkileri Bölümü.
} 
İş Kanunu’nun düzenleme alanına almadığı sendikal örgütlenmeyi yasaklayarak onu tamamlamış oluyordu.

Bu mutlak örgütlenme yasağı, 1946 yılında II. Dünya Savaşı sonrasında yaşanan görece özgürlük ortamında Cemiyetler Kanunu’ndaki yasağın kaldırılması ile sona ermiştir. 1947 tarihli ve 5018 sayılı ilk Sendikalar Kanunu’nun çıkarılmasıla ise örgütlenme hakkı sınırlı bir biçimde de olsa yasal düzenlemeye kavuşmuştur. Bu dönemde 1926 tarihli ve 818 sayılı Borçlar Kanunu'nda yer alan Umumi Mukavele (Genel Sözleşme) hem İş Kanunu hem de 5018 sayılı Sendikalar Kanunu ile hukuken kullanılabilir olsa da grev hakkının yokluğu nedeniyle Umumi Mukavele bir toplu sözleşme hakkı haline gelememiştir. Bu nedenle 1961 Anayasasına kadar sendikal hakların diğer iki sacayağını oluşturan grev ve toplu pazarlık hakları engelli ve yasaklı kalmıştır.

Türkiyede grevli ve toplu sözleşmeli sendikal hakların 1960 askeri darbesi sonrası Anayasal ve yasal güvenceye kavuşması çalışma ilişkileri ve emek tarihi yazınının tartışmalı konularından biridir. Dahası bu hakların 1980 askeri darbesi sonrasında ciddi bir biçimde sınırlanmış olması "tepeden" verilen hakların yine kolaylıkla geri alındığı yönünde değerlendirmelere yol açmıştır. 1960 sonrası yasalaşan sendikal hakların işçi hareketinin ve sendikaların bir katkısı olmadan, asker-bürokrat-aydın elitlerin çabalarıyla sağlandığı değerlendirmesi çalışma ilişkileri ve emek tarihi yazınında geniş bir yer tutmaktadır. $\mathrm{Bu}$ konudaki genel eğilim hakların oluşum sürecinde iş̧̧i hareketinin rolünü yok saymak biçiminde şekillenmiş olsa da kanımızca böyle bir değerlendirme eksik kalacaktır. Bu çalışmada Türkiye'de 1961 Anayasası ile anayasal güvenceye kavuşturulan grevli toplu sözleşmeli sendikal hakların yasalaşma aşamasında (1960-1963) gerçekleşen belli başlı işçi eylemleri incelenerek, sürece olan katkıları ortaya konmaya çalışılacaktır.

\section{0'ler İşçi Hareketi Birikiminin 'Sahneye Çıkması'}

9 Temmuz 1961'de yapılan halk oylamasında yüzde 61,7'lik oy oranıyla kabul edilen Anayasa; "Devletin sosyal adaleti sağlayacak şekilde ekonomik kalkınmayı planlama zorunluluğu..." ve "Bireyin mülkiyet ve girişim özgürlüğü hakkıyla birlikte ekonomik ve sosyal hakları..." da vaat ediyordu'. Sendikal hak ve özgürlüklerin o tarihten sonra hükümet belgelerinde yer almaya başlaması Aydın’a göre, Anayasanın bu vaadinin partiler tarafından yönerge olarak algılandığını gösteriyordu. Aydın, 29 Ağustos 1948 yılında Sadi Irmak’ın Ulus gazetesinde "CHP'nin grev hakkına karşı olduğunu" yazdığını ancak 20 Kasım 1961'de CHP Genel Başkanı İsmet İnönü başkanlığında kurulan koalisyon hükümetinin programında toplu iş sözleşmesi ve grev hakkına yer verilmesinin anayasa sonrası sendikal hak ve özgürlüklere karşı tutum değişikliğinin net bir ifadesi olduğunu belirtir².

1 Feroz Ahmad, Demokrasi Sürecinde Türkiye (1945-1980), İstanbul: Hil Yayınları, 1996, s.186.

2 Zafer Aydın, “Kanunsuz” Bir Grevin Öyküsü, Kavel 1963, İstanbul: Sosyal Tarih Yayınları, 2010, s.9. 
Feroz Ahmad'ın, “Teoride devlete sosyal adaleti sağlamak için ekonomik kalkınmayı planlama görevi verilmişti. Fakat pratikte devleti kontrol eden ve devletin çıkarlarını koruduğu güçler, mecbur bırakılıncaya kadar sosyal adalet yönünde her ilerlemeyi engelledi” ${ }^{3}$ derken işaret ettiği çelişkili durum, aslında Anayasa’nın kabulünden sendika yasalarının çıktığı 1963 Temmuz'una kadar işçi eylemlerinin arkasında yatan temel gerekçeydi. 1961 Anayasası'nda toplu sözleşme ve grev hakkı yer aldıktan sonra sendikaların talepleri grev hakkının bir an önce ve müdahalesiz bir biçimde yasal bir düzenlemeye kavuşması yönündeydi. Grev kanunu hazırlıkları sırasında, grev hakkına getirilecek sınırlamalar sendikaların büyük tepkisiyle karşılaşmıştır. 16 Temmuz 1961 tarihli Hür Vatan gazetesine açıklama yapan Lastik-İş Sendikası Başkanı Rıza Kuas, "müdahalesiz grev hakkını sonuna kadar savunacağız" derken, Maden-İş Sendikası Genel Sekreteri Ruhi Yümlü, "Müsaadeli grev, hükümetin sendikalara doğrudan doğruya müdahale etmesidir. Bunu doğru bulmuyoruz” diyerek s1nırlandırılmış bir grev hakkı istemediklerini ifade etmişlerdirł .

27 Mayıs sonrası sendikacılar arasındaki politik farklılıkların önemini yitirdiği ve daha iyi çalışma ve sosyal koşullar için mücadele bilincinin yükseldiği görülmektedir. 1960 öncesi dönemde işçi sınıfı mevcut sınırlayıcı hukuksal düzenlemeler içinde bile bir örgütlenme deneyimi yaşamış ve yeni dönem bu deneyim birikimi üzerine yükselmiştir ${ }^{5}$. 1961 sonrası işçi eylemlerinde yaşanan sıçramayı "Türkiye işçi sınıfı tarih sahnesine çıkıyordu” şeklinde yorumlayan Çelik, bu eylemlerin düşük ücretlerden, kötü çalışma koşullarına, grev yasasının çıkarılmasına, kamu işletmelerinin yöneticilerinin despot tavırlarına gösterilen tepkiye kadar geniş bir yelpazeyi kapsadığını belirtiyordu ${ }^{6}$. Fişek’in yaptığı bir derlemeye göre, sendikal yasalar çıkmadan önce 1961-63 döneminde 10 grev, 6 oturma grevi, 7 sakal grevi, 12 sessiz yürüyüş, 5 miting ve gösteri gerçekleştirilmiştir ${ }^{7} .5$ bine yakın Sümerbank işçisinin yalınayak yürüyüşü (25 Kasım 1961), Saraçhane Mitingi (31Aralık 1961), 5 bine yakın işsizin Ulus Meydanı’ndan TBMM'ye yürüyüşü ve polisle çatışmaları (Açların Yürüyüşü, 3 Mayıs 1962), Yapı-İş Sendikasının Zonguldak Ereğlisi’ndeki düzenlediği miting ve işten atmalara karşı protestolar (12-13 Ağustos 1962) ve Kavel grevi (Ocak 1963) 1961-1963 döneminde yaşanan belli başlı işçi hareketleridir ${ }^{8}$.

\section{İzmir İşçi Yürüyüşüi}

25 Kasım 1961 tarihinde Türk-İşe bağlı İzmir İşçi Sendikaları Birliği Başkanı Burhanettin Asutay’ın “(...)Artık işçi hakkını arayacak duruma gelmiştir. Birlikten kuvvet doğacağını kabul etmiştir”" diyerek öncülük ettiği İzmir İşçi

3 Ahmad, Demokrasi Sürecinde Türkiye, s.186.

4 Türk-İss, Sendikalar ve Grev Lokavt Hakları, Ankara: Türk-İş̧ Yayınları, 1964, s.38.

5 Ahmet Makal, Türkiye’de Çok Partili Dönemde Çalışma İliş̧ileri: 1946-1963, Ankara: İmge Kitabevi, 2002, s.529.

6 Aziz Çelik, Vesayetten Siyasete Türkiye’de Sendikacılık (1946-1967), İstanbul: İletişim Yayınları, 2010, s.363.

7 Kurthan Fişek, Türkiye'de Devlet-İş̧̧i İlişkileri Açısından Devlete Karşı Grevlerin Kritik Tahlili, Ankara: Ankara Üniversitesi SBF Yayınları, 1969, s.57.

8 Fişek, Türkiye'de Devlet-İş̧̧ İlişkileri, s.57.

9 “Örnek Protesto", Kim, 30 Kasim 1961, s.25. 
Yürüyüşü gerçekleşmiştir. Yüksek Hakem Kurulu'nun iş anlaşmazlıklarını sürüncemede bırakmasını protesto etmek ve "İzmir işçilerinin haklarını almak"10 hedefiyle tertiplenen yürüyüşe yaklaşık 3000 işçi katılmış ve 100 civarında pankart taşınmıştır"1. İşçilerin "Komünizmin düşmanıyız", "Grevsiz sendika olmaz", "Atatürk meşalemiz" dövizleri taşıdığı yürüyüşte çıplak ayakla yürüyen Asutay’ın boynunda "Lütuf değil hak arıyoruz ve alacağız" yazılı bir döviz asıliydi.

Çıplak ayaklarla ve takunyalı çok sayıda kadın ve erkek işçinin katıldığı sessiz yürüyüş halktan büyük destek görmüş ve Kim Dergisi'nin haberine göre yürüyüş "bu kadar nezih ve olgun bir yürüyüş daha görmedik" şeklinde yorumlayan yabancı basın tarafından filme alınmıştı ${ }^{12}$. Yürüyüşün geniş katılımlı, olaysız ve ciddiyetle tamamlanması artık işçilerin "şuurlu bir kitle haline geldiklerini” ve haklarını almada kararlı olduklarını gösteriyordu. Eylem, 15 Ekim 1961 seçimlerinin ardından, İnönü’nün hükümeti kurma çalışmalarına başladığ de 1960 sonrası yapılan ilk toplu işçi eylemi olması bakımından önemliydi.

\section{Saraçhane Mitingi}

1960 sonrası işçi eylemleri arasında şüphesiz en çok iz bırakan ve işçi hareketi tarihi açısından bir dönüm noktası sayılan Saraçhane Mitingi’dir. Türk-İş̧e bağl1 İstanbul İşçi Sendikaları Birliği'nin 31 Aralık 1961'de İstanbul'da düzenlediği ve 100 binden fazla işçinin katıldığ 1 tahmin edilen Saraçhane Mitingi, işçilerin anayasada yer alan toplu sözleşme ve grev haklarının bir an evvel yasalaşmasını sağlamak amacıyla yaptıkları eylemlerin en önemli ve kitlesel olanıdır ${ }^{13}$. Mitingin diğer bir özelliği ise doğrudan siyasal iktidara yönelik ve siyasal taleplerin dile getirildiği bir miting olmasıydı. TİP’li sendikacıların da etkin rol aldığı miting, işçi sınıfının sosyal ve siyasal anlamda da bir sınıf haline gelmekte olduğunun habercisiydi ${ }^{14}$. Boran, Saraçhane Mitingi'ni, dar anlamda işçi hak ve talepleri için yapılan bir toplantı olmaktan çok, politik bir miting olarak tanımlar ${ }^{15}$.

3 Aralık 1961 tarihli Öncü gazetesine açıklama yapan İİSB Başkanı Avni Erakalın, neden miting kararı aldıklarını şöyle açıklamıştır:

"Hükümet programında en mühim işçi konusu olan grev hakkının tahditsiz ve kısa zamanda kanunlaşacağına dair kesin bir ifade bulunmad1ğını dikkate alarak yeni hükümetin çalışmalarına ışık tutmak amacıyla 31 Aralık Pazar günü taksim meydanında ${ }^{16}$ bir açık hava mitingi yapmaya karar vermiş bulunuyoruz."

10 “Örnek Protesto", Kim, 30 Kasım 1961, s.25.

11 Türkiye Sendikacllk Ansiklopedisi, c.2, "İzmir İşç Yürüyüşü, 25.11.1961", İstanbul: Türkiye Ekonomik ve Toplumsal Tarih Vakfi, 1998, s.176

12 “Örnek Protesto", Kim, 30 Kasım 1961, s.27.

13 Artun Ünsal, Türkiye İş̧̧ Partisi, İstanbul: Tarih Vakfı Yurt Yayınları, 2002, s.72.

14 Çelik, Vesayetten Siyasete Türkiye'de Sendikacılık, s.363.

15 Behice Boran, Türkiye ve Sosyalizm Sorunlarr, İstanbul: Sarmal Yayınevi, 1992, s.79.

16 Miting ilk önce Taksim’de yapılmak istenmiş ancak dönemin valisi Refik Tulga’nın izin vermemesi üzerine Saraçhane'de yapılmasına karar verilmiştir. 
Erakalın’ın söylediği “hükümet çalışmalarına ışık tutmak amacıyla” ifadesi mitingin doğrudan iktidarı hedef aldığının bir göstergesidir. Ankara Üniversitesi Siyasal Bilgiler Fakültesi Maliye Enstitüsü’nün 20 Aralık 1961'de düzenlediği İşçi Meseleleri Semineri’nde konuşan Türk-İş Başkanı Seyfi Demirsoy ise Saraçhane Mitingi'nin esas sebebinin "hükümet programındaki grev hakkı ve toplu sözleşme bahsindeki vaadlerin ne zaman gerçekleşeceğine dair bir zaman süresi konmaması" olduğunu belirtmiş ve "bazılarının 'işçi grev istemiyor bunu birkaç sendikacı istiyor' iddialarını bir gövde gösterisiyle tekzip etmek istediklerini” ifade etmiştir ${ }^{17}$.

31 Aralık 1961 sabahı 100 binden fazla işçi yürüyüşe geçerek altı koldan Saraçhane Alanı'na girdi. İşçiler yürüyüş ve miting sırasında, "Mebusa zam işçiye gam", "Sosyal adalet istiyoruz", "şartsız grev istiyoruz", "Lütuf değil hak istiyoruz", "Patronlar Cadillac'lı, işçiler yalınayaklı", "Grevsiz sendika silahsız askere benzer", "Maaş 350, kira 150 halimiz belli”, "Grevi suç sayan zihniyet suçludur”, "Harpte en öndeyiz, hakta en arkadayı", "Göbeğimiz yok ki kemer sıkalım" gibi sloganların yazılı olduğu dövizler taşıdılar ${ }^{18}$. Öncü gazetesinin yorumuyla "kendilerine kötü sözler, yazılar yöneltilmesin diye", dövizler arasında "komüniste aramızda yer yok", "komünizme düşmanız" gibi çok sayıda antikomünist sloganın yazılı olduğu pankartlar da mevcuttu' ${ }^{19}$. Mitingin başlamasının ardından söz alan Avni Erakalın, tüm hür memleketlerde grev hakkı olduğunu, bu hakkın verilmesinin tedirginliğe yol açmaması gerektiğini belirtmiş; "Grev hakkının olduğu yerde demokrasi vardır. Bunun dışında demokrasi yoktur” diyerek grevin demokrasinin olmazsa olmazı olduğunu ve en kısa zamanda bu hakkın gerçekleşmesini istediklerini söylemiştir ${ }^{20}$. Oldukça heyecanlı bir konuşma yapan Maden-İş Sendikası Başkanı Kemal Türkler ise;

"Patron endişesinden ve baskısından kurtulmadıkça ve yarınından emin olmadıkça iktisadi hürriyetten bahsedilemez. Birçok patronlar, hakkını isteyen işçilere karşı 'Ben fabrikanın duvarlarını yüksek yaptırdım. Buradan içeri kanun giremez. Benim kanunum paradır’ diyor. İşçilerini limon gibi sıkıp, sonra posa gibi atmak istiyorlar. Hakkını almak için direnen işçiler ise vatan hainliği ve komünistlikle itham ediliyorlar (...) Vaatlere inanmıyoruz, tatbikat istiyoruz. Grev en tabii hakkımızdır, vermezlerse biz almasını biliriz"21.

diyerek bu konudaki kararlılıklarını dile getirmiştir. Daha sonra söz alan Tekgıda-İş Sendikası Genel Başkanı İbrahim Denizcier’in, "Ya grev hakkı verilecek ya da biz yasağa rağmen grev yapacağız." diyerek grev hakkının tanınmaması durumunda yapılacak grevlerden işçilerin sorumlu tutulmayacağını söylemesi $^{22}$ Aydın'a göre Kavel grevinin işaret fişeği anlamına geliyordu. Petrol-İş

17 “İşçi Grev Hakkını Ciddiye Aldığını Mitingde Gösterecek”, Öncü, 21 Aralık 1961, s.1

18 Yıldırım Koç, Türkiye Sendikacılık Ansiklopedisi, c.2, "Saraçhane Mitingi”, İstanbul: Türkiye Ekonomik ve Toplumsal Tarih Vakfı Yayınları, 1998, s.567.

19 "Sendikacılar Grev ve Kollektif Akit İstedi", Öncü, 1 Ocak 1962, s.1

20 "Sendikacılar Grev ve Kollektif Akit İstedi”, Öncü, 1 Ocak 1962, s.1.

21 Koç, "Saraçhane Mitingi", s.567.

22 Koç, "Saraçhane Mitingi", s.567. 
Sendikası Başkanı Ziya Hepbir ise görece daha yumuşak bir konuşma yaparak niyetlerinin hükümete karşı gelmek olmadığını belirtmiş ve "henüz yeterli bir çalışma düzenine sahip olmayan koalisyon hükümeti(nin), geçmişte düşülen hatalara düşmemesini, programında yer alan hususları güven oylaması sonunda unutmamasını" istediklerini vurgulamıştır. Ecevit'in bakan olmadan önce söyledikleri ile bakan olduktan sonraki uygulamaları çelişmediği takdirde Türk işçisinin her zaman onunla beraber olduğunu ve hükümetin bakanın faaliyetlerine engel olmamasını dilediklerini ifade etmiştir ${ }^{23}$.

Mitingde son sözü alan Türk-İş Başkanı Seyfi Demirsoy ise;

"Grev ve kolektif iş akdini Türk işçisi değil, bir avuç sendikacı istiyor diyenlere bu heybetli topluluk en iyi cevaptır (...) Hiç kimseden sadaka istemiyoruz. İş gücümüzün alın terimizin, nasırlı ellerimizin ve mesaimizin karşılığını istiyoruz. İşçiyi istismar ederek, onun sırtından yükselen bir cemiyette demokrasiden bahsedilemez. Anayasayı çiğnemek isteyenler karşılarında sendikaları bulacaklardır. Grev hakkını ve kolektif çalışma akdini programına koyan karma hükümeti ve onun aydın çalışma bakanını destekliyoruz"24

diyerek hükümetten anayasanın özüne uygun düzenlemeleri en kısa zamanda gerçekleştirmesini talep etmiştir.

Kim dergisi, mitingi, “Türk işçisi, ilk defa ve böylesine azametli bir topluluk halinde bir araya toplanmış, davasını kendine yaraşır ağırbaşlılık içinde ortaya atıp, aynı şekilde dağılmıştı" 25 şeklinde yorumlamıştı. Gerçekten de Saraçhane Mitingi, işçilerin politik bilinçliliğinin sınırlılığına karşın kendi taleplerini ilk defa bu kadar kitlesel bir biçimde ortaya koymalarını sağlayan bir miting olmuştur. Çelik'in ifadesiyle Türkiye işçi sınıfının tarih sahnesine çıkışı ve işçi hareketi açısından bir dönüm noktası olan bu eylem sonrasında işçi hareketinin yükselişi başlamıştır ${ }^{26}$. Saraçhane Mitingi, yeni hükümeti işçi sorunlarına eğilmeye zorlama hedefine yönelik en önemli işçi gösterilerindendir.

\section{Açların Yürüyüişï}

Bu dönemin ilginç ve önemli eylemlerinden bir diğeri, Türkiye Yapı-İş Federasyonu üyesi işçilerin 3 Mayıs 1962'de Ankara'da yaptı̆̆ 1 ve yankı uyandıran izinsiz yürüyüştür ${ }^{27}$. Açların Yürüyüşü (İşsizlerin Yürüyüşü) olarak bilinen bu eylem, Fukara Tahir olarak bilinen Tahir Öztürk’ün başkanlığındaki Yapı İşçileri Federasyonu’nun örgütlediği 5000 civarındaki inşaat işçisinin, işkolundaki yaygın işsizliği protesto etmek, asgari ücretin saptanması ve çalışma koşullarının düzeltilmesi talepleriyle TBMM’ye yaptığı yürüyüştür ${ }^{28}$.

23 "Sendikacılar Grev ve Kollektif Akit İstedi”, Öncü, 1 Ocak 1962, s.5.

24 Koç, "Saraçhane Mitingi”, s.568.

25 "Miting", Kim, 3 Ocak 1962, s.22.

26 Çelik, Vesayetten Siyasete Türkiye'de Sendikacılık, s.365.

27Türkiye Sendikacılık Ansiklopedisi, c.1, "Açların Yürüyüşü”, İstanbul: Türkiye Ekonomik ve Toplumsal Tarih Vakfi Yayınları, 1998, s.2.

28 M. Şehmus Güzel, Türkiye’de İşçi Hareketi, Ankara: İmge Kitabevi Yayınları, 2016, s.196. 
26 Nisan 1962 günü başvurulan Ankara Valiliği’nden yürüyüş izni alınamamış olmasına rağmen, 3 Mayıs 1962'de Yapı-İş Federasyonu binası önünde toplanan ve ellerinde üzerinde "niçin bu sefalet solculara fırsat için mi?","Atatürk her şeyimizdir", "tarla verin ekelim, iş verin yapalım veya bir yol gösterin gidelim”, “Türk işçisi aç ve işsiz olabilir ancak komünist olamaz", "Lafla peynir gemisi yürümez, iş istiyoruz", "Çalışın çok çalışın! Nerede?” gibi sloganların yaz1lı olduğu pankartlar olan 5000 civarındaki işsiz inşaat işçisi TBMM'ye doğru yürüyüşe geçti ${ }^{29}$. Polisin engelleme çabaları ve barikatlar aşıldı ancak meclisin önünde işçiler asker müdahalesi ile karşılaşt $1^{30}$. Emniyet mensupları müdahale ile işi halledemeyeceklerini anlayınca işçi grubundan yirmi kişilik bir heyeti meclis ve senato başkanları ile görüştürmeyi teklif etti. İşçileri dinleyen başkanlar bu dertlerin hepsinin farkında olduklarını, "kısa süre içinde yatırımların başlayacağını (...) ve inşaat mevsiminin açılacağını (...) ve bu talepleri Başbakan ve Çalışma Bakanı’na tekrar iletece(klerini)” söylediler ${ }^{31}$.

İşçi temsilcileri meclisteyken dışarıda pek çok işçi dövüldü ve gözaltına alındı. Eylem sonucu herhangi bir hak elde edilemedi ancak kamuoyunda oldukça ilgi uyandırdı ve destek gördü. Akis Dergisi'ndeki imzasız bir yazı, millete defalarca başlayacağı haberi verilen yatırımların hala neden başlamadığını sorarken ilgili bakanları suçluyor ve “(...)ve açlar yürüyor! Elbette yürüyecek İsmet İnönü! Tek başlarına sihirbazlar marifet gösterir. Memleketler ise ekiple idare edilir.” ${ }^{32}$ diyerek yürüyüşün haklılığını vurguluyor ve hükümetin harekete geçmesi gerektiğini söylüyordu. Yön Dergisi ise eylemi şöyle yorumluyordu"33: "Hareket her türlü destekten ve yöneticiden mahrum olduğu halde, şuurlu ve ölçülüydü. Aç işçiler, hiçbir taşkınlıkta bulunmadılar. Lüzumsuz müdahaleler olmasa belki de en ufak bir hadise çıkmayacaktı. Fakat yalınayakların yürüyüşü, yalınayak olmayanları ürküttüğü için coplar işledi.”

\section{Kavel Grevi}

1960-1963 döneminin hem nitelik hem de sonuçları itibariyle en çok iz bırakan direnişi Kavel Grevi'dir. 1962 yılının ikinci yarısında, patrona iş yerindeki üretimi arttırmayı taahhüt ederek işbaşına gelen yeni genel müdür İbrahim Üzümcü, işçilerin 1957'den beri kıdemine göre aldığı ikramiyenin miktarını ve ödeme şartlarını değiştirme kararı aldı. Böylece pek çok işçi ikramiye alamaz duruma gelirken, kalanlar da eskisinden oldukça düşük bir miktar almaya başlamışt ${ }^{34}$.

Kazanılmış haklarının keyfi bir biçimde ortadan kaldırılması işçileri rahatsız etmiş ve işçiler üyesi oldukları Maden-İşs sendikasının da bilgisi dâhilinde bu kararı protesto etmek için 31 Aralık 1962 günü iş yavaşlatma eylemlerine başlamışlardır. İşveren işten atma tehdidi ile sendikadan ayrılmaya zorladığı işçiler

29 “Laf değil, Af değil, İş, İș!”, Kim, 9 Mayıs 1962, s.20

30 Yıldırım Koç, Türkiye İş̧̧i Sınıfı Tarihi, Osmanlidan 2010’a, Ankara: Epos Yayınevi, 2010, s.229.

31 "Laf değil, Af değil, İş, İș!", Kim, 9 Mayıs 1962, s.23

32 “Kör Bir Hükümet!”, Akis, 7 Mayıs 1962.

33 "İșsizlerin Yürüyüșü”, Yön, 9 Mayıs 1962, s.5-6.

34 Aydın, “Kanunsuz” Bir Grevin Öyküsü, s.23-24. 
üzerinde etkili olamayınca dört işçiyi işten çıkarır. Bu olay üzerine Kavel işçileriyle görüşen Maden-İş Başkanı Kemal Türkler grev önerir. Grevin yasal olmadığı itirazlarına karşı "haklarını almak için başka bir yol olmadığını” söyler ve yaşanabilecek her türlü olumsuzluğa karşı işçileri uyarır. Aydın’ın 2008 yılında, Kavel işçilerinden Şaban Sansar'la yaptığı görüşmede ${ }^{35}$, Sansar’in o toplantıda Türkler'e "ikramiye için bu kadar risk almaya gerek var mı?” sorusu karşısında abisi Ali Sansar’ın verdiği yanıt işçi sınıfının hakları için ortaya koyduğu irade bakımından önemlidir: "Biz sadece ikramiye için grev yapmayacağız. Türkiye işçi sınıfının önünü açmak için grev yapacağız. Yasa mecliste. Fakat bir türlü çıkmıyor. Yasanın çıkması için belli insanların bir şey yapması lazım onu da biz yapacağı."

Grev oylaması yapılmış ve çoğunluk “evet” demiştir. Grev hakkının, Anayasada yer almasına rağmen henüz yasalaşmadığg hatta yürürlükte olan 3008 sayılı İş Kanunu'na göre yasak olduğu bir dönemde bir sendikanın grev kararı alması ve kararın üyeler tarafından benimsenmesi oldukça zor bir iştir. O dönem Maden-İş Sendikasında yöneticilik yapan Şinasi Kayàya göre Kemal Türkler o günkü toplantıda şunları söylemiştir ${ }^{36}$ :

"İşvereninizin bu yasadışı tutumuna karşı Anayasadaki hakların kullanılmas1 gerekir. Anayasa’nın 47. maddesi, 'İşçiler işverenle olan münasebetlerinde iktisadi ve sosyal durumlarını korumak veya düzeltmek amacıyla toplusözleşme ve grev hakkına sahiptirler. Grev hakkının kullanılması ve istisnaları ve işverenlerin hakları kanunla düzenlenir' demektedir. Biz bu hakkımızı yani Anayasal hakkımızı kullanmalıyız. Aradan geçen bunca zamana rağmen, toplu sözleşme grev yasası çıkarılmamıştır, bize göre bu kasten ve bilerek bir savsaklamadır. Bu bir gasptır, önlenmelidir. Siz Kavel işçileri olarak bu işe öncülük edeceksiniz ve böylece Türkiye’de Anayasa’ya dayanarak bir hakkın kullanılabileceğini herkese göstereceksiniz. İnanıyorum ki, bu sayede sözü geçen yasaların çıkmasını da sağlayarak Türk işçisine önderlik edeceksiniz.”

28 Ocak 1963’te başlayan ve 36 gün süren grev uygulama itibariyle "kanunsuz" olsa da hem Anayasa’nın grev hakkını tanımış olması, hem de edindiği toplumsal destek sayesinde meşru bir grev olarak algılanmıştır. Diğer taraftan hükümetin, iki bakanını arabulucu olarak görevlendirerek ${ }^{37}$ greve doğrudan müdahil olması hem grevin meşruiyetinin hem de eylemin ne derece önemsendiği ortaya koymuştur.

Grev taraflar arasında imzalanan protokolle 3 Mart 1963’te başarılı bir biçimde tamamlanır. Protokolle ikramiyelerin ödenmesinin kabul edilmesi, 4 işçi hariç işten çıkarılan diğer işçilerin işe alınması, tazminatsız olarak işten çıkarılan 4 işçinin tazminatlarının ödenmesi karara bağlanmış, işçilerin talepleri büyük ölçüde yerine getirilmiştir ${ }^{38}$. Aydın, Kavel grevini hem dar hem de geniş anlamıyla bir hak grevi

35 Aydın, “Kanunsuz” Bir Grevin Öyküsü, s.28.

36 “40 Yll Sonra Kavel’e Dönmek”, Evrensel Gazetesi, 27 Ocak 2003, https://www.evrensel.net/haber/138570/40-

yil-sonra-kavel-e-donmek, erişim tarihi: 9 Temmuz 2017.

37 "Kavel", Kim, 8 Mart 1963, s.23.

38 “Kavel”, Kim, 8 Mart 1963, s.25. 
olarak tanımlamıştır. Dar anlamda bir hak grevidir. Çünkü işçilerin kazanılmış hakları olan ikramiyelerinin ödenmemesi sonucu başlamıştır. Geniş anlamda bir hak grevidir. Çünkü, Kavel grevi doğrudan olmasa da dolaylı olarak bir grev hakkı talebidir ve grev kanununa bir müdahale çabasıdır. İçeriğine doğrudan bir etkisi olmasa da grev kanununun çıkışını hızlandırmıştır ${ }^{39} .3008$ sayılı yasadaki grev yasağına rağmen grevin kamuoyunda meşru olarak görülmesi kaotik bir durum yaratmış ve egemen çevreleri rahatsız etmiştir. Bu nedenle pek çok kesimde grev kanunun bir an evvel çıkması gerektiği fikri dile getirilmiştir. Nitekim, grevin başlamasından kısa süre sonra 18 Şubat 1963'de Grev ve Toplu Sözleşme Kanunu meclise getirilmiştir ${ }^{40}$. Kavel direnişi, sendikalar arasındaki anlayış farklılıklarını da su yüzüne çıkarmış ve DİSK'in kuruluşuna giden yolu açmıştır. Maden-İş sendikası ortaya koyduğu mücadeleci sendikal anlayış ve kazandığı prestijle DİSK'in kuruluşunda öncü bir rol oynamıştır. İşçiler arasında hak arama bilincinin gelişmesine büyük katkı yapan Kavel grevi, dile getirilen taleplerin ancak eylemin gücüyle dikkate alındığını ve hak aramanın bu temelde geliştirilebileceği doğrultusunda bir bakış açısı sağlamıştır ${ }^{41}$.

\section{Sonuç}

Sendikal hakların elde edilmesi/kazanılması mücadelesinde şüphesiz en çok göz ardı edilen ve aslında en çok incelenmeye değer birikim sendikal alana ilişkin olanıdır. 1960 sonrası işçi hareketinde ortaya çıkan canlanmanın anayasal güvence sayesinde bir anda ortaya çıktığını söylemek 1950'lerin birikimini yok saymak anlamına gelir. Bu canlanma 1950'ler boyunca biriken deneyim ve enerjinin 1960'ların başında uygun kanallar bularak ortaya çıkması şeklinde okunmalıdır. Aksi takdirde, İstanbul İşçi Sendikaları Birliği'ne bağlı sendikalar tarafından 1961 yılında gerçekleşen Saraçhane Mitingi’nde sıkıyönetim koşulları altında, 100 bin civarında işçinin sendikal yasaların çıkması için bir araya gelmesini salt kurumsal yapı değişikliği ile açıklamak olanaklı değildir. Yine 1963 tarihli sendikal yasalar Meclis’te görüşülürken örgütlenen ve yasaların hazırlanmasını hızlandıran Kavel Grevi de işçilerin grev hakkı talebi yönündeki iradelerini ortaya koydukları önemli bir örnektir.

İşçi sınıfının tüm hukuksal engellemelere ve dönemin vesayetçi yapısına rağmen ortaya koyduğu hak mücadelesine yönelik irade küçümsenmeyecek orandadır. Sendikal haklarının bilincinde olan ve grev hakkı istediğini her ortamda dile getiren, bununla ilgili çeşitli kampanyalar başlatan bilinçli bir grubun varlığını görmekteyiz.

Elbette ki 1961 Anayasası ve sonrasındaki sendikal yasaların oluşum sürecinde işçi mücadelesinin tek ya da en önemli belirleyici olduğunu söylemiyoruz. Ancak Türkiye'de yaygın olarak tercih edilen, işçi sınıfı mücadelesini veya birikimini 1960'lardan başlatma eğilimi, o tarihte yükselen mücadelenin yalnızca

39 Aydın, "Kanunsuz” Bir Grevin Öyküsü, s.141.

40 Aydın, “Kanunsuz” Bir Grevin Öyküsü, s.132-133.

41 Aydın, “Kanunsuz” Bir Grevin Öyküsü, s.142. 
Anayasa ve yasalarla bağlantılı olduğunu düşünmek anlamına gelir. Böyle bir düşünce 1960 öncesi birikimi yok saymaya, dahası toplumsal yaşamın çok faktörlü, çok yönlü ve çok düzeyli gelişim sürecini ihmal etmeye yol açacaktır.

\section{Kaynakça}

“40 Y1l Sonra Kavel’e Dönmek”. Evrensel Gazetesi. 27 Ocak 2003.

Ahmad, Feroz. Demokrasi Sürecinde Türkiye (1945-1980). İstanbul: Hil Yayınları, 1996.

Aydın, Zafer. “Kanunsuz” Bir Grevin Öyküsü, Kavel 1963. İstanbul: Sosyal Tarih Yayınlar1, 2010.

Boran, Behice. Türkiye ve Sosyalizm Sorunları. İstanbul: Sarmal Yayınevi, 1992.

Çelik, Aziz. Vesayetten Siyasete Türkiye'de Sendikacılık (1946-1967). İstanbul: İletişim Yayınları, 2010.

Fişek, Kurthan. Türkiye'de Devlet-İşçi İlişkileri Açısından Devlete Karşı Grevlerin Kritik Tahlili. Ankara: Ankara Üniversitesi SBF Yayınları, 1969.

Güzel, M. Şehmus. Türkiye’de İş̧̧i Hareketi. Ankara: İmge Kitabevi Yayınları, 2016.

“İş̧i Grev Hakkını Ciddiye Aldığını Mitingde Gösterecek”. Öncü. 21 Aralık 1961.

“İşsizlerin Yürüyüşü”. Yön. 9 Mayıs 1962.

“Kavel”. Kim. 8 Mart 1963.

Koç, Yıldırım. Türkiye Isş̧̧i Sınıfı Tarihi, Osmanlı'dan 2010’a. Ankara: Epos Yayınevi, 2010.

Koç, Yıldırım. “Saraçhane Mitingi”. Türkiye Sendikacılık Ansiklopedisi, c.2. İstanbul: Türkiye Ekonomik ve Toplumsal Tarih Vakfı Yayınları, 1998, 566-568.

“Kör Bir Hükümet!”. Akis. 7 Mayıs 1962.

Makal, Ahmet. Türkiye’de Çok Partili Dönemde Çalışma İlişkileri: 1946-1963. Ankara: İmge Kitabevi, 2002.

“Miting”. Kim. 3 Ocak 1962.

“Örnek Protesto”. Kim. 30 Kasim 1961.

“Sendikacılar Grev ve Kollektif Akit İstedi”. Öncü. 1 Ocak 1962.

Türk-İş. Sendikalar ve Grev Lokavt Hakları. Ankara: Türk-İş Yayınları, 1964.

Türkiye Sendikacılık Ansiklopedisi, c.1. “Açların Yürüyüşü”. İstanbul: Türkiye Ekonomik ve Toplumsal Tarih Vakfı Yayınları, 1998, 2-3.

Türkiye Sendikacılık Ansiklopedisi, c.2. “İzmir İşçi Yürüyüşü, 25.11.1961”. İstanbul: Türkiye Ekonomik ve Toplumsal Tarih Vakfi, 1998: 176.

Ünsal, Artun. Türkiye İşçi Partisi. İstanbul: Tarih Vakfı Yurt Yayınları, 2002. 


\title{
View of Labour Movements of 1960-63 Period from Below
}

\author{
FEYZA TURGAY
}

\begin{abstract}
The claim that trade union rights are gained thanks to military-bureaucraticintellectual elites instead of labour movement and trade unions after 1960 has been occupying a large place in labour relations and labour history literature. Even if the general tendency in this matter is to ignore the role of labour movement, this consideration does not seem right. The issue is worth analysing with other dimensions. Attempts to start labour struggle history in Turkey from the 1960's mean that the rising struggles of these times were only related to the constitution and laws. Such a thought will lead to ignore all struggles happened before 1960's on the one hand and the development process of social life with multidimensional and multidirectional perspectives on the other. This study investigates labour class union accumulation and its contribution to the process by evaluating the main labour movements in the time of recognition of trade union laws with right to strike in Turkey with 1961 constitution.
\end{abstract}

Keywords: Strike right, Trade union rights, 1961 Constitution, Labour movements. 